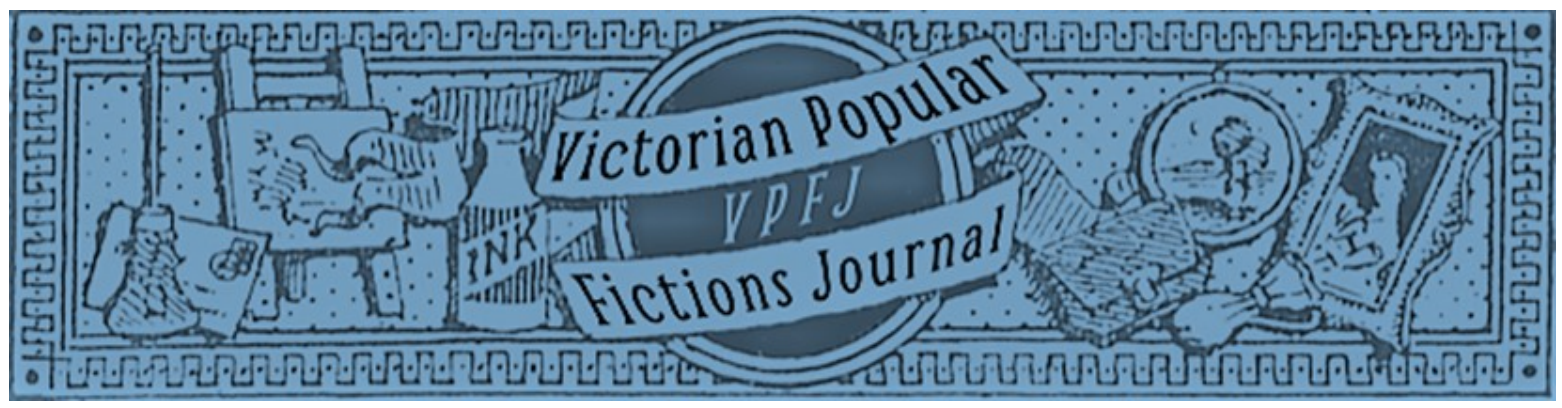

\title{
Ghost Writers: Radcliffiana and the Russian Gothic Wave
}

\author{
Katherine Bowers
}

\begin{abstract}
Ann Radcliffe's novels were extremely popular in early nineteenth-century Russia. Publication of her work in Russian translation propelled the so-called gothic wave of 1800-10. Yet, many of the works Radcliffe was known for in Russia were not written by her; rather, they were works by others that were attributed to Radcliffe. This article traces the publication and translation histories of Radcliffiana on the Russian book market of 1800-20. Building on JoEllen DeLucia's concept of a "corporate Radcliffe" in the anglophone world, this article proposes a Russian corporate Radcliffe. Identifying, classifying, and analysing the provenance of Russian corporate Radcliffe works reveals insight into the transnational circulation of texts and the role of copyright law within it, the nature of the early nineteenth-century Russian book market, the rise of popular reading and advertising in Russia, and the gendered nature of critical discourse at this time. The Russian corporate Radcliffe assures the legacy and influence of Radcliffe in later Russian literature and culture, although a Radcliffe that represents much more than just the English author. Exploring the Russian corporate Radcliffe expands our understanding of early nineteenth-century Russian literary history through specific case studies that demonstrate the significant role played by both women writers and translation, an aspect of this history that is often overlooked.
\end{abstract}

\section{Keywords}

Gothic fiction; Ann Radcliffe; Russian literature; translation; publication history; cultural transmission; textual circulation; French literature; English literature

Date of Acceptance: 8 December 2021

Date of Publication: 17 December 2021

Double Blind Peer Reviewed

\section{Recommended Citation:}

Bowers, Katherine. 2021. "Ghost Writers: Radcliffiana and the Russian Gothic Wave." Victorian Popular Fictions, 3.2: 153-172. ISSN: 2632-4253 (online) DOI: https://doi.org/10.46911/TVCT9530

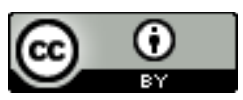

This work is licensed under a Creative Commons Attribution 4.0 International License. 


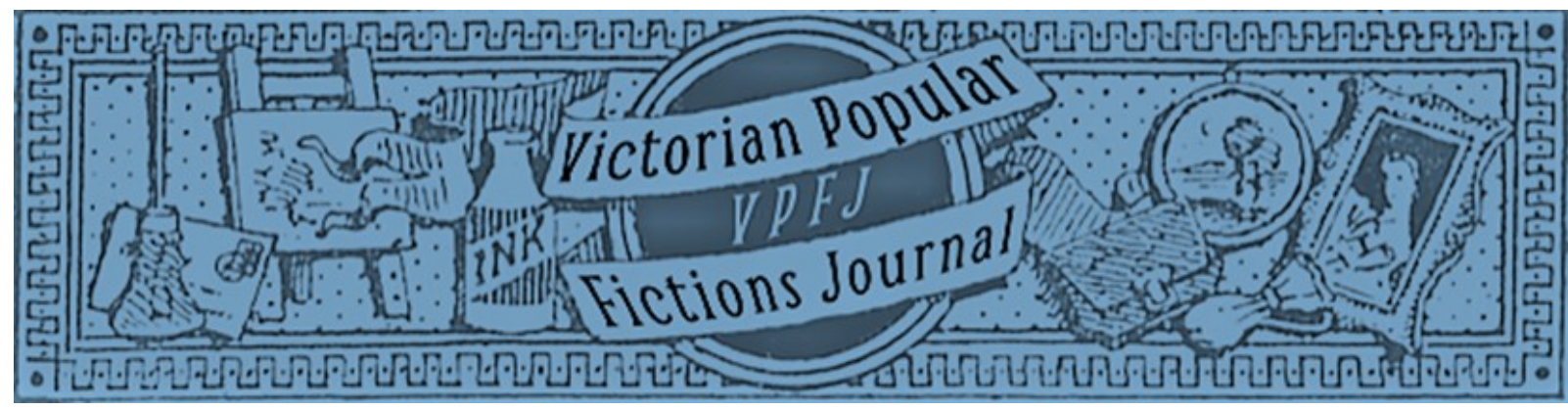

\title{
Ghost Writers: Radcliffiana and the Russian Gothic Wave
}

\author{
Katherine Bowers*
}

\section{Introduction}

Fedor Dostoevskii was an Ann Radcliffe fan. Famously, in Winter Notes on Summer Impressions (1863), he recalls having her works read aloud to him as a child.

On long winter evenings, I listened because I could not yet read, mouth agape and dying from delight and horror, as my parents read Ann Radcliffe's novels aloud to me. Then I would rave about them deliriously in my sleep.

$\left([1863]\right.$ 1973: V.46) ${ }^{1}$

Radcliffe's novels clearly made an impression on the young Dostoevskii. ${ }^{2}$ Nicknamed "the Enchantress" in deference to her skill in building immersive narrative worlds, Ann Ward Radcliffe (1764-1823) was the most popular novelist in late eighteenth- and early nineteenth-century Europe; her popularity in Russia, which imported much of its reading material from France, comes as no surprise. Between 1789 and 1798, the English writer published five novels: The Castles of Athlin and Dunbayne (1789), A Sicilian Romance (1790), The Romance of the Forest (1791), The Mysteries of Udolpho (1794), and The Italian (1797). Of these five, the latter three gained extraordinary fame. After The Italian appeared, Radcliffe disappeared from public life, but those initial five novels lived on, gaining new readers as they were translated into other languages - including French, German, and Russian - and traversed Europe.

\footnotetext{
* I would like to thank John Ayliff, Connor Doak, Tatiana Filimonova, Kate Holland, and the journal's anonymous reviewers for their attentive reading and constructive comments on my text. An early version of this article was presented as a working paper in May 2021 for the Anglo-Russian Research Network and I am grateful for the productive discussion and feedback from the group at that event as well as to Ben Phillips, who organised it. Finally, I would like to thank Deborah Martinsen for her encouragement to follow the curious trail of Russian Radcliffiana that resulted in this article.

${ }^{1}$ This translation and all others in this article, unless indicated otherwise, are my own.

2 On Dostoevskii's interest in Radcliffe's work, see Grossman (1925: 24-35); Miller (1995); Bowers (2021); Bowers (2022).
} 
Radcliffe's particular style of gothic fiction came to define many of the genre's conventions. Her novels are mostly set in temporally distant, exotic, and potentially sublime places - many in Italy - and feature innocent heroines who must contend with wicked guardians, murderers and thieves, the supernatural, kidnappings, and other tribulations. In Udolpho, Radcliffe's most well-known and influential novel, heroine Emily St Aubert is driven from her home, orphaned, robbed, imprisoned by an unscrupulous guardian, and set upon by bandits, yet also falls into reveries as she travels through the beautiful countryside of southern France, the Alps, and Italy. In a letter to his friend Iakov Polonskii, Dostoevskii admits that his dream of travelling to Italy is grounded in his early reading of these works.

How many times have I dreamed, since childhood, of visiting Italy. Ever since Radcliffe's novels, which I had already read before I was eight, various Alfonsos, Catarinas and Lucias have been imprinted on my brain. And I still rave about the Don Pedros and Donna Klaras.

([1861] 1985: XXVIII.2.19)

Dostoevskii's statement reveals more than his love of Radcliffe, however. It also reveals a peculiar knock-on effect of Radcliffe's unprecedented popularity. Although Dostoevskii associates these characters with Radcliffe, none of them appear in Radcliffe's novels, as Boris Tikhomirov has argued. Rather, they are all from "pseudo-Radcliffe" [psevdo-Radklif] novels, to use Vadim Vatsuro's term (2002: 55). "Pseudo-Radcliffe" has come to describe the substantial body of gothic novels attributed to Ann Radcliffe that appeared on the Russian book market in the early nineteenth century, but which were actually the work of other authors. Book catalogues from the period 1800-20 reveal twenty-two unique works attributed to Radcliffe (who had written only five unique novels by 1820 , one of which did not appear in Russian translation until much later). These works were published under Radcliffe's name because her name alone was enough to sell novels. Radcliffe's enormous popularity and disappearance from public life following the publication of The Italian in 1797 created a situation that fostered the production of pseudo-Radcliffe novels as demand existed, but no supply and also no international copyright law.

In this article I will use the term "Russian corporate Radcliffe" to refer to the Russian Radcliffe corpus - that is, Radcliffe's original works as well as the pseudo-Radcliffe works attributed to her and related critical and public discourse. Here I rely on the concept of “corporate Radcliffe," coined by JoEllen DeLucia (2020: 95), which, in DeLucia's work, refers to the large body of texts published in England that were associated with Radcliffe but not necessarily written by her. The Russian corporate Radcliffe is different from DeLucia's vision of the English body of texts in that it exists not only because of economic circumstances and marketing, but also as the result of a rich history of translation and transnational cultural exchange.

The Russian corporate Radcliffe corpus presents intriguing case studies, each a microhistory that provides insight into the transnational circulation of texts, the nature of the early nineteenth-century Russian book market, the rise of popular reading and advertising in Russia, and the gendered nature of critical discourse at this time. In analysing these case studies, this article will explore the phenomenon of transnational and transcultural literary ghostwriting and its role in creating Radcliffe's Russian identity, which influenced Russian literature for decades after her final novel appeared posthumously in 1826. Examining these publishing 
microhistories and the curious situations that, at times, resulted from them, reveals that Ann Radcliffe's reach in Russia goes well beyond just Radcliffe, the English author who wrote The Mysteries of Udolpho and a handful of other titles. Rather, through the body of corporate Radcliffe and critical and popular discourse surrounding it, Radcliffe in Russia became an entity that represents both the entire gothic genre of writing and latent anxieties about women stepping out of the bounds of their proscribed roles within society.

\section{Translation and the Transnational Gothic Wave}

Gothic novels were not a Russian invention, nor were they considered to be "good literature" by critics. Yet, they were extremely popular - one of the first examples of mass-produced fiction - and significantly influenced the way reading culture and literary fiction developed in nineteenth-century Russia. The gothic wave, which had been gradually building across Europe in the 1780s, hit Russia in the early 1790s with the Russian translations of Clara Reeve's The Old English Baron (1792), ${ }^{3}$ William Beckford's Vathek (1792), and Sophia Lee's The Recess, or a Tale of Other Times (1794). These Russian translations were all created from French versions of the English novels and published between 1792 and 1794 . As with many gothic novels, titles were adjusted for better sales: Reeve's translated novel was titled The Knight of Virtue: a Story from the Most Ancient Notes of English Chivalry [Rytsar' dobrodeteli: Povest', vziataia iz samykh drevnikh zapisok angliiskogo rytsarstva] while Lee's novel appeared as The Dungeon, or Matilda [Podzemel'e, ili Matil'da]. The first Russian edition of The Recess included a description that spoke to the popularity of the work as well as its translation history: "Translated into French from the 12th English edition, and from French into Russian." These translated gothic novels were successful in the 1790s, but they were a prelude to the decade known as the "Russian gothic wave," 1800-10 (Vatsuro 2002: iii). This was a period of intense literary translation as gothic novels were imported from England, France, and Germany, often in French translation, and then quickly rendered into Russian to meet the public's demand.

The late eighteenth-century Russian book market differed significantly from its counterparts in England and France. The English and French markets had been in place for well over a century and the trend for gothic novels in the 1780s was facilitated by a robust network of publishers, booksellers, circulating libraries, subscription libraries, and literary journals. ${ }^{4}$ However, this context also shaped gothic fiction. In England, a 1771 change in copyright law that negated copyrights older than 28 years led publishers, who could no longer rely on the profits from their back catalogues, to seek out new talent with more urgency. ${ }^{5}$ The result was a sharp rise in the number of individual writers being published as well as better payment for authors whose works were likely to sell well. Following Radcliffe's first best-seller,

\footnotetext{
${ }^{3}$ On the translation of Reeve's novel into Russian, see Vatsuro (2002: 52-68).

${ }^{4}$ Feather (2006) gives a good overview of the English book market (69-142). See especially 120-31 on the rise of the novel in the context of the English publishing industry.

${ }^{5}$ On the English copyright law of 1771 and its aftermath, see Feather (1994: 90-6).
} 
The Romance of the Forest, she received an unheard-of $£ 500$ for The Mysteries of Udolpho and, following a bidding war, an even more lavish $£ 800$ for The Italian. ${ }^{6}$ In comparison, in 1803 a then-unknown Jane Austen received $£ 10$ - a more typical fee for the time - in exchange for the rights to her first novel, Susan, the Radcliffe parody later published as Northanger Abbey (1818). ${ }^{7}$

In addition to finding new talent, the market for translations boomed. There was no international copyright agreement in place governing the rights to translations. As a result, French translators "plundered" - to use Angela Wright's phrasing (2014: 222) - the works of Ann Radcliffe and other English gothic novelists, which proved exceedingly popular on the French book market. ${ }^{8}$ In 1797, five Radcliffe novels were published in French translation: The Castles of Athlin and Dunbayne, A Sicilian Romance, The Mysteries of Udolpho, and The Italian. The Italian, the story of the orphan Ellena's forbidden romance with young nobleman Vivaldi and the challenges the pair face at the hands of an evil Marchesa, a wicked monk, the Inquisition, and various other obstacles, was published that year in two different translations, one by Mary Gay for Lepetit and a second by André Morellet for Denné. The mass translation and publication of Radcliffe's entire oeuvre to date followed on the success of the first French edition of The Romance of the Forest, the story of a mysterious woman named Adeline who takes shelter with a family staying in a ruined abbey while also being pursued by a villainous Marquis, which was published in François Soulès's translation by Denné in 1794. This translation boom was supported by both popular demand and a large supply of translators. Translation of popular fiction provided needed income for educated nobles and academics who had lost their fortunes or positions in the Revolution; the translator of Udolpho was the Countess Victorine de Chastenay-Lanty while Morellet, the translator of The Italian, was a well-known economist and philosophe who had previously contributed to the Encyclopédie, but who had lost his pension when the Académie française was dissolved in 1793. ${ }^{9}$ In 1798, public demand resulted in a second edition of Soulès's translation of The Romance of the Forest as well as two more editions of Morellet's translation of The Italian, which were published by Maradan, one as part of a collected works edition in multiple volumes.

\section{The Rise of Pseudo-Radcliffe}

As Radcliffe's popularity grew, these editions began to publicise that she was the author of other works. The sequence of publication can be traced through the title pages of the 1797 translations: Gay's translation of The Italian proclaimed the work to be by the author of The Romance of the Forest, while Morellet's translation of the same stated the work was by the author of The Romance of the Forest and The Mysteries of Udolpho. Moylin Fleury's translation of $A$ Sicilian Romance included Radcliffe's previous authorship of The Romance of the Forest, The Mysteries of Udolpho, and The Italian as a selling point. Pseudo-Radcliffe novels existed

\footnotetext{
${ }^{6}$ On Radcliffe's contracts and the bidding war for them, see Norton (1999: 94-5).

${ }^{7}$ For a detailed account of this history, see Burns (2021: 1-30).

${ }^{8}$ On the translation of gothic novels in France, see Wright (2014: 221-30).

${ }^{9}$ On the translation of Radcliffe into French and her translators, see Prungnaud (1994: 16-23).
} 
on the French market as well; The Tomb [Le tombeau], for example, was published under Radcliffe's name in 1799. ${ }^{10}$ The multitude of translators and publishers, marketing techniques, and Radcliffe editions that appear in short succession on the French book market underscore its flexibility and scope. ${ }^{11}$

Unlike the English and French book markets, the Russian market was relatively new, having formed in large part following Catherine II's granting of printing privileges to private presses in the 1770s. This expansion of printing into the private sphere, albeit still regulated by the state, enabled the growth of a book market; in the mid-1770s there were just fifteen booksellers in Russia, but by the 1790s there were fifty, and by the turn of the nineteenth century there were hundreds. ${ }^{12}$ The introduction of gothic fiction to Russia coincided with both this sharp rise in the market's capacity and the further loosening of censorship and regulation of private printing following Alexander I's ascension to the throne in $1801 .{ }^{13}$ As more private printing presses were established, literary journals flourished as well. The demand for reading material rose significantly faster than Russian writers were able to produce it and translations dominated the market at this time. ${ }^{14}$

The first Russian readers of Radcliffe were undoubtedly reading French translations imported from abroad (Vatsuro 2002: 114). The first Russian language Radcliffe edition was Pavel Cherniavskii's translation of The Romance of the Forest, which appeared under the title The Forest, or the St Clair Abbey [Les, ili Sent-Klerskoe abbatstvo] in 1801. Translators like Cherniavskii and Fedor Zagorskii worked from French imports. In addition to regulating printing presses, the government controlled what was printed, a history that shaped the catalogue of available texts as well as their timing on the market. For example, Zagorskii submitted his translation of The Mysteries of Udolpho to the Russian censor for approval in 1799, just two years after the novel came out in France, but the manuscript was delayed at the censor for three years. ${ }^{15}$ Zagorskii's translation of The Mysteries of Udolpho appeared in 1802 and that year alone seven translations of novels attributed to Radcliffe entered the Russian book market. If you search for Ann Radcliffe's name in the Russian State Library catalogue, a number of familiar titles will come up in Russian translation, among them The Mysteries of Udolpho [Tainstva Udol'fskie] and The Italian, or the Confessional of the Black Penitents [Italiianets, ili Ispovednaia chernykh kaiushchikhsia]. Some of her

\footnotetext{
${ }^{10}$ The Tomb will be discussed in more detail later in this article.

${ }^{11}$ Darnton gives an excellent overview of the eighteenth-century French book market, both legal and pirated (2021: 45-58).

${ }^{12}$ On the development of the eighteenth-century Russian book market, see Marker ([1985] 2014: 152-211).

${ }^{13}$ On the expansion and trends of the Russian book market in the early nineteenth century, see Tosi (2006: 33-44).

${ }^{14}$ On the Russian translation market, see Tosi (2006: 91-3).

${ }^{15}$ On Radcliffe's original translation into Russian, see Vatsuro (2002: 116-17).
} 
novels appear under their French titles, like The Forest, mentioned above, or Julia, or the Dungeon of Madzini [Iuliia, ili Podzemel'e Madzini], originally titled A Sicilian Romance. ${ }^{16}$ They were extremely popular, as demonstrated by the quick succession in which Radcliffe's novels were published, as well as the vast array of imitators and pseudo-Radcliffe works that appeared after.

Given Radcliffe's popularity and her scant bibliography, it is not surprising that the vast majority of titles under Radcliffe's name in the Russian State Library catalogue are pseudo-Radcliffe works. Some of these novels are well known and their attribution to Radcliffe would confuse anyone familiar with early eighteenth- and nineteenth-century gothic novels, such as The Monk, or the Pernicious Consequences of Ardent Passions [Monakh, ili Pagubnyia sledstviia pylkikh strastei] by Matthew Lewis. The Monk recounts the scandalous history of a monk called Ambrosio who, tempted by a demon called Matilda, inadvertently makes a deal with the devil in order to satisfy his carnal appetites. The Monk's appearance in the catalogue under Radcliffe's authorship is particularly surprising because of Lewis's novel's notoriety and the fact that its aesthetic style is commonly opposed to Radcliffe's (including by Radcliffe herself). ${ }^{17}$ Radcliffe's own novels tend to have a sentimental aesthetic that enables the reader's connection with her pensive heroines, even if the works include frightening scenes, wicked foes, and an assortment of spooky props like a skeleton in a chest or a wax effigy of a corpse. Lewis's novel, on the other hand, is written in a style intended to shock readers. In one particularly graphic scene, for example, a woman who has been confined to a dungeon with her dead child recounts the way her fingers, embracing the child, pushed through the corpse's rotting flesh and became tangled with worms. In another scene, the devil reveals to the monk Ambrosio that, not only has he committed murder and rape, but also incest, since his victim was also secretly his sister. The Russian translators of Lewis's novel, Ivan Pavlenkov and Ivan Rosliakov, worked from the 1797 French translation of the text, which was anonymously attributed. Radcliffe's name was likely added to improve sales during 1802, the year of Radcliffe's explosive popularity in Russia (Vatsuro 2002: 210). The practice of translators or publishers adding Radcliffe's name to otherwise anonymous texts is common among the pseudo-Radcliffe novels. Pavlenkov went on to translate the luridly titled Albert's Castle, or the Animated Skeleton [Zamok Al'berta, ili Dvizhushchiisia skelet], a work of unknown authorship, which also came out under Radcliffe's name. However, the practice resulted in curious inconsistencies as additional works were translated and published. In Russia, The Monk was widely known as Radcliffe's novel until the Russian translation of The Bravo of Venice was published in 1807. The Bravo of Venice, echoing its French source text, included the line on its title page: "The work of Msr Lewis, the author of The Monk" [Sochinenie g-na Levisa, avtora Monakha]. ${ }^{18}$

\footnotetext{
${ }^{16}$ Vatsuro identifies the translator of A Sicilian Romance [Iiuliia, ili Podzemel'e Madzini] as poet Andrei Maksimovich (2002: 126-7).

${ }^{17}$ Radcliffe makes this aesthetic argument in "On the Supernatural in Poetry" (1826).

${ }^{18}$ In 1805, Lewis published a translation of Heinrich Zschokke's play Abällino der grosse Bandit (1794) called The Bravo of Venice, A Romance. The English edition included the line "translated from the German" prominently displayed on its frontispiece, but did not attribute authorship even in Lewis's translator's preface. The French translation of The Bravo of Venice appeared in 1806, attributing authorship to Lewis, "Auteur du Moine" [author of The Monk]. The Russian translation, done from the French, appeared in 1807, also attributing authorship to Lewis, "avtora Monakha" [author of The Monk].
} 
Francis Lathom's The Midnight Bell (1798) has a particularly curious history in this regard. The novel was published anonymously in 1798, although Lathom went on to have a career as a popular author under his own name afterwards. Famously, The Midnight Bell appeared in Austen's Northanger Abbey as one of the so-called Northanger Canon, the list of gothic novels Isabella Thorpe recommends heroine Catherine Morland. For decades, this list, including The Midnight Bell, was considered by scholars to be largely fake, a collection of lurid titles Austen had fabricated for comedic effect. ${ }^{19}$ But research into the transnational afterlives of gothic works demonstrates that the work was both widely available and even parodied by other writers of the time outside of Great Britain. In the same year of its English publication, the novel was translated into French, also anonymously. Two versions of the novel, both translated from the French, appeared on the Russian book market in 1802. One of these, the St Petersburg translation, was done by Rosliakov and attributed to an anonymous author, as Lathom's novel had been in its original printing. The other, the Moscow translation, was anonymously translated and appeared under Radcliffe's authorship. The translations both appeared around the same time and clearly used the same French source text (both indicate that they are translations from the French and only one French translation existed at this time). Their existence highlights the lack of copyright law in effect in Russia in the early nineteenth century; the first legal statutes relating to copyright were introduced only in 1828. Before then, publishers were unmotivated to pay much for new work and translation was in high demand, but paid extremely poorly. The pseudo-Radcliffe Moscow translation of The Midnight Bell went through multiple editions, printed first in 1802, then in 1803, and again in 1816. Its popularity can be shown through its appearance in later works. In 1823, the playwright Boris Fedorov included a merchant selling a copy of The Midnight Bell in his play Captain Gromilov while in 1833 gothic novelist Orest Somov included the work as reading material for his heroine in the story "Mommy and Sonny" [Matushka i synok], a gothic spoof.

\section{The Curious Histories of "Radcliffe Translation"}

Radcliffe's name was a significant marketing benefit as the attribution of The Monk and the afterlife of The Midnight Bell demonstrates. The history of another pseudo-Radcliffe novel, Rodolphe, or the Cavern of Death in the Deep Forest [Rodol'f, ili Peshchera smerti v dremuchem lesu], demonstrates how easily others' authorship could be attributed to Radcliffe. The English original, The Cavern of Death. A Moral Tale, was published anonymously in 1794. Its French translation was published by Maradan in 1799, also anonymously. The first Russian edition (1801), which was published before Radcliffe's works began to appear in Russian translation, also had anonymous authorship on the frontispiece. In 1806, this same Russian translation of The Cavern of Death was reprinted by two different publishers, however, and both reprints were attributed to "Mrs Radcliffe." Attributed authorship is a fluid category on the early nineteenth-century Russian book market. Adding Radcliffe's name to the later printings of The Cavern of Death was a strategy to improve its sales, but other authors' names were invoked in the process of selling the text. A bookseller advertising new titles for sale in a

This is the first work attributed to Lewis to appear in Russia. The 1805 reprint of The Monk was also attributed to Radcliffe.

19 This view was put forward by Victorian critic George Saintsbury (1891: 19), among others, and refuted by book collector Michael Sadleir (1927: 91-106), who tracked down the full group of novels. 
February 1801 issue of St Petersburg News [Sanktpeterburgskie vedomosti] mentions a stock of The Cavern of Death by Ducray-Duminil, a French novelist whose recent work, Lolotte and Fanfan, or the History of Two Children Abandoned on a Desert Island, was popular. ${ }^{20}$ The 1801 edition of The Cavern of Death has no mention of authorship; the bookseller uses Ducray-Duminil's name to bring in more customers.

Translations were completed hastily and, in some cases, by multiple translators working on parts of the same text simultaneously. An anonymous piece in the journal The Flower Garden [Tsvetnik] laments this practice, observing:

All the immortal creations, such as, for example, the novels of Mr Ducray-Duminil, Mrs Radcliffe, and others like them, which have in the title attractive words like abbey [abbatstvo], mystery [tainstvo], hut [khizhina], house [domik], boy [mal'chik], girl [devochka], and so on and so forth, are translated suddenly by the volume [chast'] and sometimes even by the sheet [list] by different translators. These zealous translators are like tailors' apprentices who, in a few hours, sew a whole men's suit for one person and receive only a tip for their labour. It is a pity that, despite the same haste in their work, tailors always have the advantage in that they finish a garment.

(1810: 419-20)

This quotation reveals the speed of this work, the lack of compensation for translators, and the assumed poor quality of the resulting translations. The list of "attractive" title words also speaks to the idea that certain title styles, like certain authors' names, sell books. Translators of texts by Radcliffe were able to negotiate significantly higher rates of compensation for their work after the 1801 Russian edition of The Romance of the Forest and the many Radcliffe works published in 1802, which assured her fame among Russian readers. ${ }^{21}$

As a result of this premium for Radcliffe translations, several of the corporate Radcliffe works are simply translations of French novels with Radcliffe's name attached. Mathurin-Joseph Boullault's evocatively titled 1801 novel The Living Phantom, or The Neapolitans, an anecdote taken from a manuscript found on the banks of the Thames [Le Fantôme vivant, ou Les Napolitains, anecdote extraite d'un manuscrit trouvé sur les bords de la Tamise] became The Living Corpse, or the Neapolitans [Zhivoi mertvets, ili Neapolitantsy] by Ann Radcliffe in Russian translation. Martha Hugill's novel Isidora of Gallicia (1797-8) was translated into French as The Castle of Galicia [Le château de Gallice] and attributed to Hugill in 1798. In 1802 the novel appeared in Russian translation as The Castle in Galicia [Zamok v Galitsii] without attribution of author or translator. But in 1808 the Russian publisher brought out a second edition of the same translation with a new title, The Castle, or Nocturnal Specters in the Western Tower of the Black Forest and the Mysteries of Orlando [Zamok, ili Nochnyia privideniia v zapadnoi bashne chernago lesa i tainstva Orlanda], attributed to Mrs Radcliffe. In 1811, Louis-Antoine Marquand's novel Amanda, or Night Apparitions appeared in Russian translation attributed to

\footnotetext{
${ }^{20}$ Lolotte et Fanfan (1788) was published in Russian translation in 1791 and reprinted in 1793 and 1795. The editions were labeled "An English work" and attributed to Mr D. M. rather than François Guillaume Ducray-Duminil, which adds another layer of marketing.

${ }^{21}$ On rates of pay for translators, see Vatsuro (2002: 121).
} 
Radcliffe. The French source included Marquand's authorship, while the Russian translation added a more descriptive lurid title, Night Apparitions, or the Adventures of Unhappy Amanda, and the Barbarism of her Husband [Nochnyia videniia, ili Prikliucheniia neshchastnoi Amandy, i Varvarstva eia muzha], and Ann Radcliffe's name. In each of these cases, the translator or the publisher added Radcliffe's authorship deliberately as an author was clearly indicated in each French source.

A slightly greyer area of attribution are English novels that were translated into French and published anonymously there, then translated into Russian and attributed to Radcliffe. The Monastery of St. Columb, or the Knight of the Red Armor, is a Russian translation of a French translation of noted Shakespeare forger William Henry Ireland's 1805 gothic novel Gondez, the Monk. A Romance of the Thirteenth Century. The English original attributes the work to Ireland, but his attribution is lost from the French translation onward. Anne Ker's novel The Heiress di Montalde, or The Castle of Bezanto (1799) follows a similar transmission pattern; it was translated into French in 1812, but published as an anonymous English work. In both cases, the Russian translators added Radcliffe's authorship.

The history of a collection of Radcliffe's stories published in 1810 by S. I. Selivanovskii provides an even clearer example of this kind of flexible attribution. Published under the title Maria and Count M-v; or The Unhappy Russian Woman: A True Account, the work consists of two parts bound together in one volume. The first 33 pages comprise the tale of Maria and Count M-v. This work is originally Russian and was published in 1803 as Unhappy Margarita [Neschastnaia Margarita], a literary adaptation of a Russian folktale about a merchant's daughter and a yard man. The 85 pages following this tale contain the novella Pernicious Matrimony, or Blanche's Tragic Death: A Sicilian Tale [Pagubnoe supruzhestvo, ili Tragicheskaia smert' Blanshi: Sitsiliiskaia povest']. This latter story is a repackaging of Le Mariage de Vengeance, an excerpt from the longer Histoire de Gil Blas de Santillane (1715) written by Alain-René Lesage and published in Russian translation in 1792. The "translator" who found these sources and the fact that the collection proclaims that they were "translated from English" demonstrate the level of subterfuge that some were willing to carry out in the name of profit.

Maria and Count M-v and Pernicious Matrimony have the same translator listed: V. A. Ozerov. Vladislav Aleksandrovich Ozerov was a noted playwright at this time. His plays Oedipus in Athens (1804), Fingal (1805), and Dmitrii Donskoi (1807) were successful, but his final play, Polyxena (1809) was a massive flop, plunged him into poverty, and forced him to leave St Petersburg for the countryside where he could live more economically. The 1810 publication of a pseudo-Radcliffe collection bearing his name as translator implies his need for funds. The lurid, sensational titles are a far cry from the classical tragedies on which Ozerov's reputation was built. Ozerov's history gives a rare glimpse into the life of one of the corporate Radcliffe translators, the majority of whom were anonymous.

Not all of the pseudo-Radcliffe works are deceptions on the part of the Russian translators or publishers. Some of the translations - among them Apparitions in a Pyrenean Castle [Videniia v Pireneiskom zamke]; The Monastery of St Catherine, or the Customs of the $13^{\text {th }}$ Century: A Historical Novel [Monastyr' Sv. Ekateriny, ili Nravy XVIII veka; Istoricheskii roman]; The Hermit of the Secret Tomb, or the Specter of the Old Castle [Pustynnik tainstvennoi grobnitsy, ili Prividenie starogo zamka. Anekdot iz letopisei trinadsatago veka]; 
and The Tomb [Grobnitsa] - were faithful renditions of French translations, which had been falsely attributed to Ann Radcliffe on the French book market. Apparitions in a Pyrenean Castle is Catherine Cuthbertson's The Romance of the Pyrenees, originally published anonymously in England and then translated into French and attributed to Radcliffe. Two different translations appeared of the novel, both from French and attributed to Radcliffe's authorship, in 1809; the translation published by Selivanovskii gave it a new catchy title: The Horrible, Unusual, and Extraordinary Adventures, or Apparitions in a Pyrenean Castle [Uzhasnyia, neobykhnovennyia i chrezvychainyia prikliucheniia, ili Videniia v Pireneiskom zamke]. The Monastery of St Catherine was published in French in 1810 and purported to be a translation of a Radcliffe novel by composer Caroline Wuiet, Baroness Auffdiener. In reality, the novel was written by Wuiet and deliberately published as a fake Radcliffe translation. The Russian edition closely followed the French source, down to the subtitle "A historical novel." Similarly, The Hermit of the Secret Tomb appeared in French in 1816 and was marketed as a translation of Ann Radcliffe. In fact, the "translator," Étienne-Léon de Lamothe-Langon, was the author (and went on to publish a number of gothic novels and crime novels under his own name afterwards). As with Wuiet's novel, the Russian translation closely followed the French source down to the subtitle. The French translation of The Tomb was marketed as a posthumous work by the author of "L'abbaye de Ste.-Claire, des Mystères d'Udolphe, de L'Italien, etc." although it was neither by Ann Radcliffe nor was she deceased. As a result, the Russian translation included this same note on its frontispiece: "A work by Mrs Radcliffe, published after her death" (Grobnitsa 1802). The provenance of the original remains a mystery, although the French National Library catalogue entry includes a note indicating that the text was most likely written by its "translator," Hector Chaussier et Bizet.

In 1812, The Mysteries of the Black Tower was published in Moscow in Russian translation. As with many of the others, the source was a French translation of an English novel: John Palmer, Jr.'s The Mystery of the Black Tower (1796). The Mystery of the Black Tower recounts the story of a medieval peasant called Leonard whose true love Emma is kidnapped and imprisoned in the haunted Black Tower and the various adventures he has along the way to rescue her; in the end Leonard discovers his true identity. While some episodes are amusing, the novel as a whole suffers from flat characters and a disjointed narrative that is constantly interrupted by digressions. Unlike many other pseudo-Radcliffe novels, the provenance of The Mysteries of the Black Tower was publicly questioned, in particular in an April 1812 review of the novel. In his review, the critic N. gives an overview of its various entertaining plot elements, but concludes that "the novel is so stupid that ... Mrs Radcliffe never thought to write it" (310-11). He continues:

The title says she composed it, but our publishers often use such tricks to lure money from simple-minded admirers of Mrs Radcliffe. Although she has already died and all her writings have been translated into Russian, new novels are constantly being published and advertised as a new work of Mrs Radcliffe. It can be expected that, in time, the translator of Mysteries of the Black Tower will translate some other novel, calling it the Mysteries of the Yellow House, and the publisher, who has paid two rubles per five and a half sheets [listy] for the novel, will declare that it was composed by the glorious Madame Radcliffe, and, if you like, swear that she definitely lived in a yellow house and that the translator was very briefly acquainted with her there.

(N. 1812: 311) 
The reviewer makes several points here that are relevant for the purposes of this article. $\mathrm{N}$. observes that the pseudo-Radcliffe novel is aimed at "simple-minded admirers" of Radcliffe who are willing to buy any book with her name on the title page. In describing the practice of adding Radcliffe's name to a work to sell it, the reviewer suggests that this is common knowledge. Yet, $\mathrm{N}$. is mistaken to say that Radcliffe is dead - a belief stemming from the 1802 Russian publication of The Tomb, which was falsely marketed as a posthumous novel. N. concludes that faux Radcliffe novels stem from a market demand for new Radcliffe works, but no supply because of Radcliffe's death. The satirical speculation about the hypothetical publisher's attempt to authenticate the text by creating a relationship between translator and author is intriguing as well. Alleging this kind of personal relationship takes the subterfuge one degree further: first the lie about Radcliffe's authorship, then the lie about Radcliffe's acquaintance with the translator. With this observation, N. is also poking fun at the idea that a work of literature should be authenticated because it supposedly reflects the author's experience and, by extension, laughing at the gullibility of the reader. N.'s comments underscore two important points that analysing Russian corporate Radcliffe texts reveal: that pseudo-Radcliffe novels occurred in such volume because of the gap left in the market when Radcliffe retreated from public life in 1797 and that the tactics, enabled by the absence of international copyright law, used by publishers and translators were sometimes extreme.

\section{Reading Corporate Radcliffe}

Corporate Radcliffe flourished because of the entertaining thrills readers associated with Radcliffe's name. Radcliffe's novels are praised for her careful attention to her aesthetic philosophy and narrative craft, but she gained fame and readers because of the gothic suspense and thrills she incorporated into her texts. When Austen's heroine Catherine Morland and her friend Isabella Thorpe sit down to discuss The Mysteries of Udolpho in Northanger Abbey, they are delighted not by Radcliffe's masterful engagement with the sublime, but by the trappings of gothic meant to titillate readers:

"I am just got to the black veil."

"Are you, indeed? How delightful! Oh! I would not tell you what is behind the veil for the world! Are not you wild to know?"

"Oh! Yes, quite; what can it be? But do not tell me - I would not be told upon any account. I know it must be a skeleton, I am sure it is Laurentina's skeleton. Oh! I am delighted with the book! I should like to spend my whole life in reading it."

(1818: II.68)

Although Austen's readers are fictional, their articulation of the experience of reading Radcliffe's novels echoes that of historical Russian readers who appreciate the thrill of mystery, suspense, and terror. Ekaterina Sushkova, a memoirist, describes finding some volumes by Ann Radcliffe on a shelf in her aunt's library. She recalls reading them: "With what freezing of my heart I learned the theory of apparitions - sometimes it seemed to me that I saw them - they caused me fear, but some kind of pleasant fear" ([1812-41] 1928: 63). This "pleasant fear" recalls Catherine and Isabella's conversation. Mikhail Dmitriev, a poet, critic, and memoirist, remembers reading gothic fiction in his youth: 
The fashionable novels of the time were those of Mesdames de Genlis and Radcliffe. I didn't like the delicate works of the former as they always seemed saccharine, but my aunts shed a lot of sensitive tears over them. But the horrors and secrets of Madame Radcliffe fascinated me, like all the readers of that time.

([1810] 1998: 52)

Dmitriev contrasts de Genlis, a French sentimental writer, with Radcliffe's "fascinating" secrets and horrors. Aleksandr Nikitenko, a critic, censor, and academic, similarly recalls a youthful fascination with gothic novels:

The novels were largely in translation and mostly bad, without the slightest hint of psychological development in the characters. They fascinated me exclusively with romantic adventures and the fiery feelings depicted in them. With what trembling I penetrated into dark dungeons following Ann Radcliffe...! But I gained little from this course of reading: ... first, the fact that for a long while afterwards I was afraid to stay alone in a dark room, and second that, meeting a new woman, I rushed to elevate her into a pearl of creation and fall in love with her.

([1804-24] 1904: I.53)

Nikitenko mentions the poor quality of the translated novels and their lack of psychological development. Yet, his reading still contains an experiential quality; like Sushkova, he is drawn into the world of the text and has a physiological response. Austen's readers are clearly reading Udolpho, but the delightful thrills Isabella and Catherine describe are those of gothic suspense more broadly, not specifically from Radcliffe. They just happen to be reading Radcliffe. This conversation in Northanger Abbey additionally introduces the so-called Northanger canon, Isabella's recommended gothic reading list, which includes several titles actually published under Radcliffe's name in Russia. Similarly, these memoirs by early nineteenth-century Russian readers might be describing the experience of reading pseudo-Radcliffe, or Radcliffe, or both. These microhistories and memoirs point to the need for a broader definition of Radcliffe, one that DeLucia's concept of corporate Radcliffe provides.

DeLucia theorises corporate Radcliffe in the English context. Her concept refers to "an authorship that blends the known output of Ann Radcliffe with anonymous Minerva novels and the productions of the lesser-known proto-feminist writer and memoirist Mary Anne Radcliffe" (2020: 95). This conceptualisation of Radcliffe renders her not a single author, but, rather, a much larger entity encompassing the authentic Radcliffe as well as a multiplicity of experiences and understandings of the works by and attributed to her. DeLucia uses the example of the Minerva Press (1790-1820), a publishing business founded by William Lane that was known for publishing imitative gothic and sentimental novels. Although the reputation of the Minerva Press was poor, it was nonetheless popular and grew to dominate the novel publishing industry. Because the Minerva Press is associated with gothic novels and Radcliffe was the most popular gothic novelist, the two are linked together. However, Radcliffe never published with the Minerva Press (although two of the Russian pseudo-Radcliffe novels were originally Minerva Press novels: The Animated Skeleton and The Mystery of the Black Tower). ${ }^{22}$

\footnotetext{
${ }^{22}$ Lane's successor A. K. Newman issued some Radcliffe reprints decades after their initial publication. The Minerva Press, in its final year, published an edition of $A$ Sicilian Romance (1820). See DeLucia (2020: 106n1).
} 
Instead, as DeLucia argues, the Minerva Press began to find ways to generate profit from Radcliffe's name and reputation even without legal rights to her catalogue. One method was "conflating Radcliffes by omitting first names and relying on an indeterminate Mrs Radcliffe or in title pages combining the work and identities of different Radcliffes" (DeLucia 2020: 102). For DeLucia, understanding a "corporate Radcliffe privileges the textual affinities and associations created by publishers and scholars as rich transtemporal and living networks that exceed individual authors, their nations and their historical contexts" (2020: 105).

The Russian corporate Radcliffe looks different than DeLucia's corporate Radcliffe, which is grounded in the English context. Russian corporate Radcliffe must consider the four authentic Radcliffe novels published in Russia, the eighteen documented pseudo-Radcliffe works (and however many more must exist), the French source texts, the English source texts, critical discourse surrounding Radcliffe, and popular discourse about Radcliffe. As this article has demonstrated, digging into the background and history of even one Russian pseudo-Radcliffe translation opens up a multitude of other, related histories. For example, in gothic studies criticism, Matthew Lewis is often juxtaposed with Ann Radcliffe. However, considering corporate Radcliffe from the Russian context reveals Lewis's surprising connections to Radcliffe as well as the way Radcliffe's publication history in Russia shaped Lewis's Russian career.

Corporate Radcliffe also encompasses criticism of Radcliffe and pseudo-Radcliffe. In Russian criticism, Radcliffe's novels often came under fire. Whereas in the excerpt from the review of The Mysteries of the Black Tower the author, N., criticises readers for believing such low-quality writing to be Radcliffe's, others critique Radcliffe's writing for being too violent, unfeminine, or unnatural. Many of these critiques are gendered in nature. For example, in this excerpt, Vladimir Izmailov, using the pseudonym O.O.O., comments on Radcliffe's 'unwomanly' imagination.

The Englishwoman Radcliffe dedicated her pen to the most terrifying fantasies, such as could be contrived not by the heart of a woman but only by the imagination of the most passionate fanatic. We can only hope that the English Muses, having terrified us for a time with the wild horrors of Radcliffe's imagination, will soon charm us with pleasant descriptions in the style of Marmontel.

$([1804] 1903: 243)^{23}$

Here Izmailov is not discussing one work, but, rather, the body of corporate Radcliffe, all of which he assumes to be written by Radcliffe. In a similar vein, Petr Makarov reviewed The Monk as a part of Radcliffe's body of work, observing that gothic novels, "having no purpose, providing no true representation of society or people, revealing no new moral truths or new aspects of the human heart, do not have any use for any society and may be very damaging!" (1803: 218) He continued, observing that:

a protracted experience of horror works on the nerves ... [and] can sometimes lead to unhappy results; in this we call to witness all doctors. We know women who haven't slept for three nights while reading The Abbey of St Claire, or Mysteries of Udolpho. Books of that sort should carry the epigraph: et la mère en défendra la lecture à la fille [and the mother will forbid the daughter from reading it].

(1803: 218-19)

\footnotetext{
${ }^{23}$ On Izmailov's criticism of gothic novels more broadly see Vatsuro (2002: 268-71). Marmontel refers to French historian Jean-François Marmontel, who is known for his picturesque descriptions.
} 
Makarov's concerns stem from a rise in women readers, an anxiety about the possibility of women being distracted from their domestic roles, and, uniting these, a view that Radcliffe has written The Monk, a work that is wildly vulgar and scandalous. ${ }^{24}$ Strikingly, Makarov gave a positive review to Mariia Arbuzova's translation of Regina Maria Roche's The Children of the Abbey (1796; in Russian 1802-1803), which he praised for its sentimental features. ${ }^{25}$ Roche's bestselling novel recounted the history of siblings Amanda and Oscar Fitzalan who are robbed of Dunreath Abbey, their rightful inheritance, by an unscrupulous relative who forges a will. The heroine Amanda navigates interactions with a cast of society characters including a scheming Marquis and Marchioness, a villainous libertine, and the object of her affection, the dapper Lord Mortimer, as she seeks to reclaim her birth right. Roche's novel includes only one major gothic scene, when Amanda encounters the ghost of Lady Dunreath in the Abbey. In this, it is more like Radcliffe's own novels, which are suspenseful, but also imbued with sentimental feeling. Makarov's critique of Radcliffe is rather a critique of corporate Radcliffe that is, the accumulation of reputations and texts that become part of her Russian entity. However, Makarov's critique of Radcliffe also becomes part of the Russian corporate Radcliffe. Within Russian corporate Radcliffe, Radcliffe becomes a byword for the problems of modern society and literature.

In 1816, gothic novelist Orest Somov published a humorous poem called "Plan for a Novel à la Radcliffe" [Plan romana à la Radcliff]. In it, Somov plays with convention to draw up a kind of recipe or outline for a perfect Radcliffe novel:

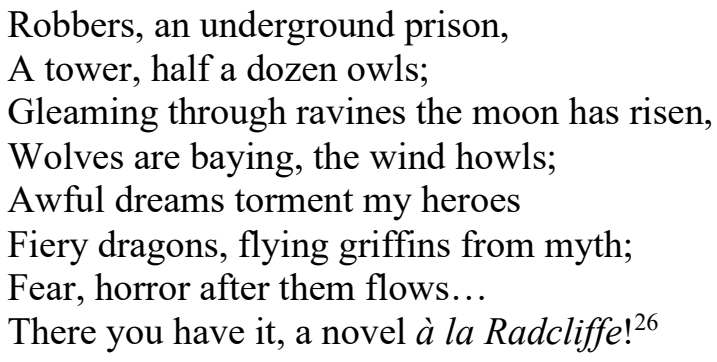

Readers familiar with Radcliffe's original five novels will be confused by this poem. It lays out many gothic conventions, but only the beginning is recognisable in Radcliffe's narrative world. The other elements, like the dragons, griffins, and so on belong to "corporate Radcliffe." Somov, familiar mainly with the corporate Radcliffe works published in Russia and not distinguishing between authentic and pseudo-Radcliffe, conflates both. His poem thus describes the Russian Radcliffe.

\footnotetext{
${ }^{24}$ For the extension of this argument, see Bowers (2020: 392-9).

${ }^{25}$ On Makarov's criticism of gothic fiction broadly, see Vatsuro (2002: 263-8).

${ }^{26}$ This rhymed translation is by Alessandra Tosi (2006: 84-5).
} 


\section{Conclusion}

The Russian Radcliffe is a combination of texts, experiences, and attitudes that transcend borders and languages. This Radcliffe collapses a decade's worth of publishing into a single year, or draws out a few short years' worth of publications into decades. This Radcliffe is a woman writer who has a reputation for violating tradition and the status quo through her scandalous and risqué novels. This Radcliffe is the work of a multitude of authors, translators, publishers, critics, and readers over the course of half a century and beyond. The latest Russian pseudo-Radcliffe novel I found, Louisa, or the Dungeon of the Lyon Castle [Luiza, ili Podzemel'e Lionskago zamka] published in 1819, presents an intriguing opportunity for speculation. The work purports to be translated from French and no translator is credited. However, the work also does not correspond to any French, German, or English gothic novel I could find. It is possible that this Radcliffe is an anonymous Russian "translator" who is consciously authoring the text as Radcliffe's. The other twenty-one Russian corporate Radcliffe texts I found clearly map to French or English source texts, and their provenance through translation - or, in the case of Ozerov's "translation" of Maria and Count M-v, blatant copying of earlier Russian publications - is clear. However, Louisa's origin remains a mystery. Whether it is a translation of a lost or unknown text or the creation of an unknown Russian author, by 1819, this text is the last in a long line of corporate Radcliffe works. In its attribution to Radcliffe, it carries the reputation of that line: both the probability of popularity and the association with lurid gothic thrills and scandal.

Despite the rich history of Ann Radcliffe's transmission, publication, and popularity in Russia, scholars often cite Nikolai Karamzin's short gothic story "Bornholm Island" [Ostrov Borngol'm] from 1794 as the apogee of the gothic genre in Russian literature. Karamzin's story is a familiar tale: a traveller comes upon a menacing castle while exploring a distant island. There he finds a mystery and ultimately discovers the daughter of the house imprisoned in a cave beneath it for transgressions too unspeakable to write. Karamzin's story is brimming with gothic cliché and he used the genre's conventions knowingly. During the 1790s, Karamzin embarked on an informal study of genre fiction, writing and publishing a number of works clearly situated within specific genres he had encountered on his 1789-90 trip through Western Europe, among them the sentimental tale, the historical adventure, and the gothic tale. Karamzin's foray into the gothic has since become the primary example of Russian gothic for Russian literature scholars. The prevalent narrative within Russian literary history is that gothic fiction represents a curiosity, a brief period when a handful of writers produced generically derivative texts that was quickly overturned by romanticism and the rise of the romantic fantastic. However, this narrative does not take popular reading and its influence into account. Furthermore, the story of Russian literature is usually told through a national paradigm so only works by Russians or in Russian are included; translations are largely treated as being of secondary importance. Karamzin's gothic story may seem a literary curiosity to Russian literature scholars, but its prominence in the canon today belies the history, popularity, variety, and volume of gothic texts that appeared on the Russian book market during the period 1790-1820, crucially developed by women's writing and via translation. Exploring the Russian corporate Radcliffe not only reveals the depth of Radcliffe's afterlife in Russia, but also challenges the conventional narrative of Russian literary history. 
As this article has demonstrated, Radcliffe and pseudo-Radcliffe works had a vibrant afterlife. They also shaped Russian fiction. References to corporate Radcliffe texts are sprinkled across the major nineteenth-century Russian novels, among them Fathers and Children (1862) and War and Peace (1865). In the letter to Polonskii that opened this article, Dostoevskii states that, by 1829 , he had read all of Radcliffe - including, as we know, a lot of pseudo-Radcliffe. His final novel Brothers Karamazov (1880) refers specifically to The Mysteries of Udolpho:

It's just this consideration that has led the prosecutor to assume that the money is hidden in some hole at Mokroe. Why not in the dungeons of Udolpho, gentlemen? Isn't this supposition really too fantastic and romantic?

([1880] 1976: XV.158)

This is the lawyer Fetiukovich's speech in defence of Dmitrii Karamazov, who has been accused of patricide. In this courtroom scene, Fetiukovich brings up Udolpho in an attempt to cast aspersions on the prosecution's assumptions. Fetiukovich's dismissal of the dungeons of Udolpho as a romantic fantasy, one that a serious person would not entertain, echoes the reading of many critics before him. By 1880, however, the "gothic wave" when Radcliffe's books were bestsellers that virtually everyone read was seventy years in the past. The scene, however, suggests that the memory of Radcliffe persisted. For Dostoevskii's readers, a reference to the "dungeons of Udolpho" would evoke not just the English writer, but also the rich body of corporate Radcliffe works that came to represent a delightfully thrilling reading experience for generations afterwards.

\section{Bibliography}

Austen, Jane. 1818. Northanger Abbey and Persuasion, 4 vols. London: John Murray.

[Beckford, William]. 1792. Kalif' Vatek. Arabskaia skazka. St Petersburg: Tipografii Gornago uchilishcha.

Boullault, Mathurin-Joseph. 1801. Le Fantôme vivant, ou Les Napolitains, anecdote extraite d'un manuscrit trouvé sur les bords de la Tamise. Paris: Marchand.

Bowers, Katherine. 2020. "The Gothic Novel Reader Comes to Russia.” In Reading Russia. A History of Reading in Modern Russia, vol. 2, edited by Damiano Rebecchini and Raffaella Vassena, 377-408. Milan: Ledizioni.

Bowers, Katherine. 2021. "Under the Floorboards, Over the Door: The Gothic Corpse and Writing Fear in The Idiot." In Dostoevsky at 200: The Novel in Modernity, edited by Katherine Bowers and Kate Holland, 137-58. Toronto: University of Toronto Press.

Bowers, Katherine. Forthcoming 2022. Writing Fear: Russian Realism and the Gothic. Toronto: University of Toronto Press.

Burns, Margie. 2021. Publishing Northanger Abbey: Jane Austen and the Writing Profession. Wilmington: Vernon Press. 
The Cavern of Death. A Moral Tale. 1794. London: J. Bell.

[The Cavern of Death] La Caverne de la Mort. 1799. Trans. L. F. Bertin. Paris: Maradan.

[The Cavern of Death] Rodol'f, ili Peshchera smertiv dremuchem lesu, trans. S. R. Moscow: Tipografiia Senata u Selivanovskago.

[Cuthbertson, Catherine]. 1803. Romance of the Pyrenees. London: G. and J. Robinson.

[D. M.] Ducray-Duminil, François Guillaume. 1791. Lolotta i Fanfan, ili Prikliucheniia dvukh mladentsov, ostav na neobitaemom ostrove, trans. Foma Rozanov. Moscow: Tipografiia Kompanii tipograficheskoi.

Darnton, Robert. 2021. Pirating and Publishing: The Book Trade in the Age of Enlightenment. Oxford: Oxford University Press.

DeLucia, JoEllen. 2020. "Radcliffe Incorporated: Ann Radcliffe, Mary Ann Radcliffe, and the Minerva Author." Romantic Textualities: Literature and Print Culture, 1780-1840, 23 (Summer): 94-108. DOI: https://doi.org/10.18573/romtext.74

Dmitriev, M. [1810] 1998. Glavy iz vospominanii moei zhizni, edited by K. G. Bolenko, E. E. Liamina, and T. F. Neshumova. Moscow: Novoe literaturnoe obozrenie.

Dostoevskii, F. M. 1972-90. Polnoe sobranie sochinenii $v 30$ tomakh. 30 vols. Leningrad: Akademiia nauk.

Feather, John. 1994. Publishing, Piracy, and Politics: An Historical Study of Copyright in Britain. London and New York: Mansell.

Feather, John. 2006. A History of British Publishing, $2^{\text {nd }}$ edition. New York and London: Routledge.

Fedorov, Boris. 1824. Rotmistr Gromilov. Original'naia komediia. St Petersburg: tipografiia Plavil'shchikova.

Grossman, Leonid. 1925. Poetika Dostoevskogo. Moscow: Internatsional'naia "Mospoligraf."

Hugill, Martha. 1797-8. Isidora of Gallicia, a novel. London: Lee and Hurst.

Hugill, Martha. 1798. Le Château de Gallice, trans. P. L. Lebas. Paris: Tavernier.

[Hugill, Martha]. 1802. Zamokv Galitsii. Moscow: Tipografiia Kriazheva, Got'e \& Meia.

Ireland, William Henry. 1805. Gondez, the monk. A Romance of the Thirteenth Century. London: W. Earle.

[Ireland, William Henry]. 1810. Le Monastère de St. Columba, ou le Chevalier des armées rouges, trans. M-me ***. Paris: J. G. Dentu.

Izmailov, Vladimir [O. O. O.]. [1804] 1903. "Vzgliad na povesti, ili skazki." In Iz istorii russkogo romana i povesti, edited by V. V. Sipovskii. St Petersburg: imp. Akademiia nauk.

Karamzin, N. M. 1794. "Ostrov Borngol'm.” Aglaia. 1: np.

[Ker, Anne]. 1799. The Heiress di Montalde, or The Castle of Bezanto. London: Earle and Hemet.

[Ker, Anne]. 1812. L'héritière de Montalde, ou Le spectre et les mystères du château de Bezanto, trans. A.C.A. Rouargue. Paris: Pigoreau.

Khvostova, E.A. [1812-41] 1928. Zapiski: 1812-1841, edited by Iu. G. Oksman. Leningrad: Academia.

[Lathom, Francis]. 1798a. La cloche de minuit. Paris: Au bureau de librairie chez H. Nicolle.

[Lathom, Francis]. 1798b. The Midnight Bell, a German Story; Founded on Incidents in Real Life. London: H.D. Symonds.

[Lathom, Francis]. 1802. Polnochnoi kolokol, ili Tainstva Kogenburgskago zamka, trans. Ivan Rosliakov. St Petersburg: I. Kadesftskii korpus.

Lee, Sofia. 1794. Podzemel'e, ili Matil'da. Moscow: Tipografii A. Reshetnikova.

Lesage, Alain-René. 1715. Histoire de Gil Blas de Santillane. Paris: Pierre Ribou. 
Le Sazh, Alen Rene. 1792. Pokhozhdenie Zhilblaza de Santillany, trans. Vasilii Teplovyi. St Petersburg: Imp. Akad. Nauk.

[Lewis, Matthew]. 1796. The Monk: A Romance. London: J. Bell.

[Lewis, Matthew]. 1797. Le Moine, trans. J. M. Deschamps, J. B. D. Desprès, P. V. Benoist, and P.B. de Lamare. Paris: Maradan.

Lewis, M. G. [Heinrich Zschokke]. 1806. Le Brigand de Venice, trans. P. de C***. Paris: Dentu.

Lewis [Levis], M. G. [Heinrich Zschokke]. 1807. Razboinikv Venetsii, trans. S. P. Moscow: Tipografiia Dubrovina and Merliakova.

Makarov, P. 1803. "Retsenziia na Monakha.” Moskovskii Merkurii, 218-19.

Marker, Gary. [1985] 2014. Publishing, Printing, and the Origins of Intellectual Life in Russia, 1700-1800. Princeton, NJ: Princeton University Press.

Marquand, Louis-Antoine. 1801. Amanda, ou les apparitions nocturnes. Paris: Tiger.

Miller, Robin Feuer. 1995. "Dostoevskii and the Tale of Terror." In Dostoevskii and Britain, edited by W. J. Leatherbarrow, 139-58. Oxford: Berg Publishers.

Neschastnaia Margarita. Istinnaia rossiiskaia povest'. 1803. Moscow: F. Gippius.

Nikitenko, A. V. [1804-24] 1904. Moia povest' o samom sebe i o tom, 'chemu svidetel' v zhizni byl': Zapiski i dnevnik (1804-1877), edited by M.K. Lemke, 2 vols. St Petersburg: Tipo-Litografiia "Gerol'd".

Nikol'skii, P. A. [N.]. 1812. Review of Tainstva chernoi bashni. Sankt-Peterburgskii vestnik, 2.6: $310-11$

Norton, Rictor. 1999. Mistress of Udolpho: The Life of Ann Radcliffe. London: Leicester University Press.

Palmer, John, Jr. 1796. The Mystery of the Black Tower. London: Minerva Press for William Lane.

Palmer, J. H. 1797. Les Mystères de la Tour Noire. Paris: Tavernier.

Prungnaud, Joëlle. 1994. "La traduction du roman gothique anglais en France au tournant du XVIIIe siècle." TTR 7:1: 16-23. DOI: https://doi.org/10.7202/037167ar

[Radcliffe, Ann]. 1789. The Castles of Athlin and Dunbayne. A Highland Story. London: T. Hookham.

[Radcliffe, Ann]. 1790. A Sicilian Romance. London: T. Hookham.

[Radcliffe, Ann]. 1791. The Romance of the Forest: Interspersed with some pieces of poetry. London: T. Hookham and J. Carpenter.

Radcliffe, Ann. 1794. The Mysteries of Udolpho, a romance; interspersed with some pieces of poetry, etc. London: G.G. and J. Robinson.

Radcliffe, Ann. 1797. The Italian, or The confessional of the Black Penitents: A romance. London: T. Cadell Jun. and W. Davies.

Radcliffe, Ann. 1826. "On the Supernatural in Poetry." New Monthly Magazine, 16.2: 145-52.

Radcliffe, Anne. 1794. La forêt, ou L'abbaye de Saint-Clair, trans. François Soulès. Paris: Denné.

Radcliffe, Anne. 1797a. Éléonore de Rosalba ou Le confessionnal des pénitens noirs, trans. Mary Gay. Paris: Lepetit.

Radcliffe, Anne. 1797b. Julia, ou Les souterrains du chateau de Mazzini, trans. Moylin Fleury. Paris: A.Cl. Forget.

Radcliffe, Anne. 1797c. Les chateaux d'Athlin et de Dunbayne, histoire arrivée dans les montagnes d'Écosse, trans. François Soulès. Paris: Testu, 1797.

Radcliffe, Anne. 1797d. Les mysteres d'Udolphe, trans. Victorine de Chastenay. Paris: Maradan.

Radcliffe, Anne. 1797e. L'Italien, ou Le confessional des pénitens noirs, trans. André Morellet. Paris: Denné. 
Radcliffe, Anne. 1798a. La forêt, ou L'abbaye de Saint-Clair, trans. François Soulès. Paris: Maradan.

Radcliffe, Anne. 1798b. L'Italien ou Le confessionnal des pénitens noirs, trans. André Morellet. Paris: Maradan.

Radcliffe, Anne [Hector Chaussier et Bizet]. 1799. Le tombeau, trans. Hector Chaussier et Bizet. Paris: André.

Radcliffe, Anne [Catherine Cuthbertson]. 1809. Les visions du château des Pyrénées. Paris: Renard.

Radcliffe, Anne [Caroline Auffdiener, neé Wuiet]. 1810. Le Couvent de Sainte Catherine, ou Les Moeurs du XIIIe siècle; Roman historique. Paris: Renard.

Radcliffe, Anne [Étienne-Léon de Lamothe-Langon]. 1816. L'hermite de la tombe mystérieuse, ou Le fantôme du vieux château: anecdote extradite des annals du treizième siècle, trans. Étienne-Léon de Lamothe-Langon. Paris: Ménard et Desenne.

Radklif, Anna. 1801. Les, ili Sent-Klerskoe abbatstvo, trans. Pavel Cherniavskii. Moscow: Tipografii A. Reshetnikova.

Radklif, Anna. 1802a. Tainstva Udolf'skie, trans. Fedor Zagorskii. 4 vols. Moscow: Tipografiia A. Reshetnikova (vol. 1), Tipografiia Kriazheva, Got'e, i Meia (vols. 2-4).

Radklif, Anna. 1802b. Iiuliia, ili Podzemel'e Madzini, trans. Maksimovich. Moscow: Universitetskaia Tipografiia.

Radklif, Anna. 1802-4. Italiianets, ili Ispovednaia chernykh kaiushchikhsia. Moscow: Tipografiia Kriazheva, Got'e, i Meia, (vol. 1, 1802), Tipografiia S. Selinovskago (vols. 2-3, 1803-4).

Radklif, Anna [Matthew Lewis]. 1802. Monakh, ili Pagubnyia sledstviia pylkikh strastei, trans. Ivan Pavlenkov and Ivan Rosliakov. St Petersburg: Imperatorskaia akademiia nauk.

Radklif, Anna [Francis Lathom]. 1802. Polnochnoi kolokol, ili Tainstva Kogenburgskago zamka. Moscow: Tipografii Selivanovskago.

Radklif, Anna [Hector Chaussier et Bizet]. 1802. Grobnitsa, trans. A. S. Moscow: Tipografii Selivanovskago.

Radklif, Anna [Unknown]. 1803. Zamok Alberta, ili Dvizhushchiisia skelet, trans. Ivan Pavlenkov. St Petersburg: 1. Kadetskii korpus.

Radklif, Anna [Unknown]. 1806a. Peshchera smerti $v$ dremuchem lesu, trans. S.R. Moscow: A. Reshetnikov.

Radklif, Anna [Unknown]. 1806b. Peshchera smerti $v$ dremuchem lesu, trans. S.R. Moscow: Tipografiia Senata u Selivanovskogo.

Radklif, Anna [Mathurin-Joseph Boullault]. 1806. Zhivoi mertvets, ili Neapolitantsy, trans. Boris Karlovich Blank. Moscow: Tipografii Khristofora Klaudiia.

Radklif, Anna [Martha Hugill]. 1808. Zamok, ili Nochnyia privideniia v zapadnoi bashne chernago lesa i tainstva Orlanda. Moscow: Tipografiia Kriazheva, Got'e \& Meia.

Radklif, Anna [Catherine Cuthbertson]. 1809a. Videniia $v$ Pireneiskom zamke. Moscow: Universitetskaia tipografiia.

Radklif, Anna [Catherine Cuthbertson]. 1809b. Uzhasnyia, neobykhnovennyia i chrezvychainyia prikliucheniia, ili Videniia v Pireneiskom zamke. Moscow: tipografiia S. Selivanovskogo.

Radklif, Anna [Anonymous and Alain-René Lesage]. 1810. Dve povesti. Mariia i graf $M-v$, ili Neshchastnaia rossiianka: Istinnoe proizshchestvie, trans. V. Ozerov. Moscow: S. Selivanovskii.

Radklif, Anna [Caroline Auffdiener, neé Wuiet]. 1811. Monastyr' Sv. Ekateriny, ili Nravy XVIII veka; Istoricheskii roman. Moscow: Universitetskaia tipografiia.

Radklif, Anna [Louis-Antoine Marquand]. 1811. Nochnyia videniia, ili Prikliucheniia neshchastnoi Amandy, i Varvarstva eia muzha. Moscow: A. Reshetnikov.

Radklif, Anna [John Palmer]. 1812. Tainstva chernoi bashni. Moscow: A. Voeikov \& Co. 
Radklif, Anna [William Henry Ireland]. 1816. Monastyr' S. Kolumba, ili Rytsar' krasnago oruzhiia. Moscow: Universitetskaia tipografiia.

Radklif, Anna [Étienne-Léon de Lamothe-Langon]. 1818. Pustynnik tainstvennoi grobnitsy, ili Prividenie starogo zamka. Anekdot iz letopisei trinadsatago veka, trans. Anna Petrovna Tatishcheva. Moscow: S. Selivanovskii.

Radklif, Anna [Unknown]. 1819. Luiza, ili Podzemel'e Lionskago zamka. Moscow: Universitetskaia tipografiia.

[Reeve, Clara]. 1792. Rytsar' dobrodeteli: Povest', vziataia iz samykh drevnikh zapisok angliiskogo rytsarstva, trans. Kornilii Lub'ianovich. St Petersburg: Vil'kovskii.

Sadleir, Michael. 1927. "The Northanger Novels: A Footnote to Jane Austen." The Edinburgh Review, 246.501: 91-106.

Saintsbury, George. 1891. Tales of Mystery: Mrs. Radcliffe, Lewis, Maturin. New York: Macmillan.

Somov, Orest. 1816. "Plan romana a la Radcliff." Khar'kovskii Demokrit, V: 61.

Somov, Orest. 1833. "Matushka i synok."

Tikhomirov, B. N. 2020. "K probleme genezisa 'ital'ianskoi mechty' Dostoevskogo: Radklif ili psevdoRadklif?" Dostoevskii i mirovaia kul'tura, 10.2: 128-52. DOI: https://doi.org/10.22455/26190311-2020-2-128-152

Tosi, Alessandra. 2006. Waiting for Pushkin: Russian Fiction in the Age of Alexander I (1801-1825). Amsterdam: Rodopi.

Untitled. 1801. Sanktpeterburgskie vedomosti, 12 (8 February).

Untitled. 1810. Tsvetnik, 9: 419-20.

Vatsuro, Vadim. 2002. Goticheskii roman v Rossii. Moscow: Novoe literaturnoe obozrenie.

Wright, Angela. 2014. "Gothic Translation: France, 1760-1830." In The Gothic World, edited by Glynnis Byron and Dale Townshend, 221-30. London and New York: Routledge.

Zschokke, Heinrich. 1795. Abällino der grosse Bandit. Frankfurt and Leipzig: Grätz Verlag.

[Zschokke, Heinrich]. 1805. The Bravo of Venice, trans. M. G. Lewis. London: D. N. Shury. 